\title{
Clinico-Pathological and Compositional Changes in Milk of Mastitis Cows
}

\author{
Rajendra Kumar Tripathy ${ }^{1}$, Prasana Kumar Rath ${ }^{2 *}$, Bidyut Prava Mishra ${ }^{3}$, \\ Susen Kumar Panda ${ }^{2}$ and Biswadeep Jena ${ }^{4}$ \\ ${ }^{I}$ Veterinary Officer, Mobile Veterinary Unit, Veterinary Dispensary, At/Po-Angul, \\ Odisha, India \\ ${ }^{2}$ Department of Veterinary Pathology, College of Veterinary Science \& Animal Husbandry, \\ OUAT, Bhubaneswar - 751003, Odisha, India \\ ${ }^{3}$ Department of Livestock Product Technology, College of Veterinary Science \& Animal \\ Husbandry, OUAT, Bhubaneswar-751003, Odisha, India \\ ${ }^{4}$ Department of Veterinary Surgery \& Radiology, College of Veterinary Science \& Animal \\ Husbandry, OUAT, Bhubaneswar-751003, Odisha, India \\ *Corresponding author
}

\section{A B S T R A C T}

The present study was aimed to have an in-depth study on haemato-biochemical alterations in mastitis cows along with compositional changes in mastitis milk. There was an overall

\begin{tabular}{|l|}
\hline Ke y w or d s \\
Hematology, \\
Histopathology, Mastitis, \\
Milk composition, Serum \\
biochemical
\end{tabular}
incidence of $41.88 \%$ of mastitis screened on basis of clinical signs, SCC and MCMT with $77.56 \%$ subclinical mastitis and $22.54 \%$ of clinical mastitis. Hematology of mastitis cows revealed anemia with significant decrease in Hb, TEC and PCV, leucocytosis with nutrophilia, eosinophilia and lymphopaenia. Significant increase in Total Protein, AST, $\mathrm{Na}^{+}$and $\mathrm{K}^{+}$concentrations and a significant decrease in Glucose, $\mathrm{Ca}^{+}$and Phosphorous concentrations was seen in affected cows. Significant $(\mathrm{p}<0.05)$ increase in $\mathrm{pH}$, Whey Protein, $\mathrm{Na}^{+}$and electrical conductivity and a significant $(\mathrm{p}<0.05)$ decrease in specific Gravity, acidity, Fat, SNF and total protein value observed mastitis milk. Tetracycline was found as the most prevalent antibiotic residues. Histopathology of the representative tissue sample revealed the presence of ductal haemorrhages with adjacent fibrotic proliferation, polypoid fibrotic growth projecting into the lumen of teat canal, fibrosis along with inflammatory cells filled in ductal areas. Data generated during the study envisages understanding the disease severity for remedial therapy and assessing detoriation in the milk quality for food safety.

\section{Introduction}

Mastitis is the inflammation of parenchyma of mammary gland characterized by physical, chemical, compositional and usually bacteriological changes in milk and pathological changes in glandular tissues (Radostits et al., 2000).

Alterations in hemato-biochemical parameters have been correlated to aid diagnosis as well as treatment. Early detection with suitable 
tests, timely intervention with effective treatment and prevention is necessary to restrict the spread of mastitis (Guha and Gera, 2011). Patho-morphological changes in glandular tissue owing to mastitis results in compositional changes in milk leading to unsuitable for consumption.

Keeping in view of the high rate of prevalence as well as devastating production loss in relation with both quantity and quality of milk and possibility of permanent teat damage, this study is designed to have a detailed study on clinic-pathological changes associated in mastitis cows.

\section{Materials and Methods}

Screening of cows to study incidence of mastitis

The cows domesticated in and around Bhubaneswar were included in the present research programme randomly screened for detection of mastitis on the basis of history from the owner about reduced milk yield, presence / absence of abnormality in milk such as flakes, clots, and watery milk, bloods or gels or precipitates in milk, Presence / absence of clinical signs, somatic cell count of the milk samples (SCC) and Modified California Mastitis Test (MCMT).

During screening, the cows were grouped as sub-clinical and clinical mastitis basing on SCC and CMT score along with signs of inflammation in udder and gross abnormal composition of milk.

\section{Collection of Milk Sample}

Milk samples were collected aseptically from the mastitis cows. Samples were labeled properly after collection and then transferred to the laboratory for further laboratory works like cytology and SCC besides CMT done instantly at the field at owners door step.

\section{California Mastitis Test (CMT)}

The rapidity and amount of gel formation or precipitate is measured qualitatively to assess the severity. The test was done as per the standard procedures described by Schlam and Noorland (1957).

\section{Somatic Cell Count (SCC)}

The procedure followed was according to the general principle of Prescott and Breed method as detailed by Schalm et al., (1971). Cells from 25 fields were counted, averaged and multiplied by $5^{*} 10^{5}$ to get the total number of somatic cells $/ \mathrm{ml}$ of milk.

\section{Compositional changes in milk}

Alterations in milk composition in mastitis cows by comparing with the milk from normal but apparently healthy cows in relation to consistency, $\mathrm{pH}$, specific gravity, fat $\%$, $\mathrm{SNF} \%$, acidity, total protein, whey protein and $\mathrm{Na}^{+}$concentrations were seen. The data obtained was analyzed by various statistical methods.

\section{Antibiotic Residues in Mastitis Milk}

Ten mastitis milk samples selected for QuickSTAR strip reader for possibility regarding presence of any antibiotic residues.

\section{Haemato-biochemical examinations}

Blood sample from the apparently healthy lactating cows as well as cows suffering from mastitis were subjected to detailed haematobiochemical estimation. Serum samples were estimated in Automatic Biochemical Analyser (Turbo Chem 100) using commercially available ICHEM kits manufactured by Jeev diagnostics and the methods of analysis were as per the manufacturer's instruction. Hemoglobin percentage was estimated as per the Sahali's method. 


\section{Histopathology of Mastitis Udder Tissue}

The representative tissue samples were collected by curetting from the blocked quarters of chronic mastitis cases $(n=6)$ and processed for routine histopathology under routine H\&E stain. Data generated in the study analyzed by using SAS software package.

\section{Results and Discussion}

There was an overall prevalence of $41.88 \%$ out of 234 cows screened for mastitis on basis of clinical signs, SCC and MCMT. Average SCC of $2.5-4.0$ lakhs/ml without any gross abnormality of udder considered as subclinical mastitis and more than 4.0 lakhs/ml of SCC with presence of clinical signs related to udder gross pathological changes considered as clinical mastitis. Below 2.5 lakhs $/ \mathrm{ml}$ of SCC without any obvious changes in milk as well as udder considered as normal and apparently healthy but non-mastitis cows. Cows were screened for MCMT and scored accordingly $3+$ i.e. (Distinct slime formation which adheres to the bottom of the paddle) of $17,2+$ (slime formation) i.e.19, $1+$ (distinct precipitate but no tendency towards gel formation) i.e. 62 and 136, Negative (0) i.e. no evidence of a formation of a precipitate in the present study. Out of 98 cows screened positive for mastitis, 76 cows $(77.56 \%)$ were of subclinical mastitis and only 22 cows $(22.54 \%)$ were of clinical mastitis. Environmental factors such as climate, housing, and quality of indoor air, type of bedding / floor, stress and non-availability of nutrients were proven to be the predisposing factors for high incidence of the disease in this study as the cows housed in natural field conditions (Radostits et al., 2007). The earlier researchers from Odisha reported a similar higher prevalence of subclinical mastitis i.e. of $43.57 \%$ (Sahoo and Parida, 2002). Unawareness among the farmers about good managemental practices is considered for the highier prevalence of subclinical mastitis in some localities as reported by Zeedan et al., (2014).

\section{Haematological examination}

Haematological parameters were evaluated in mastitis cows and compared with apparently healthy cows depicted in Table-1. There was a significant $(\mathrm{p}<0.05)$ decrease in $\mathrm{Hb}$, TEC and PCV with significant $(p<0.05)$ increase in TLC in mastitis cows in comparison to Control cows i.e. apparently healthy but mastitis negative cows. Differential leucocyte count (DLC) of the mastitis cows showed a significant $(\mathrm{p}<0.05)$ increase in Neutrophil and Eosinophil. Sarvesha et al., (2017) observed a significant increase in TLC and lymphopenia in mastitis infected animals. Significant reduction in $\mathrm{Hb}$, TEC, and PCV values might lead to anaemia in affected animals. Increase in TLC along with nutrophilia and lymphopenia which may attribute to persistent infection in mastitis.

\section{Serum biochemical examination}

The present study showed a significant $(p<0.05)$ increase in various serum biochemical parameters like Total Protein (TP), AST, $\mathrm{Na}^{+}$and $\mathrm{K}^{+}$concentrations and a significant decrease value for Glucose, $\mathrm{Ca}^{+}$ and Phosphorous concentrations in mastitis affected cows when compared with the apparently healthy but mastitis negative control cows as depicted in Table-2. Present finding corroborates with Babaei et al., (2007); Kumar (2012) and Jain et al., (2013). Zaki et al., (2008) observed a non-significant decrease in the serum calcium and total protein values with no obvious changes in the serum phosphorus values in subclinical mastitis in comparison to the healthy control. The increased levels of various enzymes in the milk occur mainly due to the increased permeability of microcirculatory vessels in 
inflamed areas along with the leakage from degenerated/necrotic parenchymal cells and leukocytes. Increase in Total Protein may be attributed to the decreased albumin levels after the immune response to the udder infection (Singh, 2000).

\section{Compositional changes in milk}

Details of compositional changes of mastitis milk given in Table- 3 showed a significant $(\mathrm{p}<0.05)$ increase in $\mathrm{pH}$, Whey Protein, $\mathrm{Na}^{+}$ and electrical conductivity in mastitis milk in compared with normal but mastitis absent milk sample. There was a significant $(\mathrm{p}<0.05)$ decrease in Specific Gravity, acidity, Fat, SNF and total protein value in mastitis milk. This finding corroborates with Badran et al., (1986) and Haggag et al., (1991). Decrease in the specific gravity in mastitis affected cows attributed to the increase in chloride and decrease in the lactose contents. The study also reported that there is a positive correlation with the severity along with $\mathrm{pH}$ of the milk in mastitis. The decreasing trend in the specific gravity in mastitis milk owes to the reduced lactose contents and increased chlorides.

Higher levels of citrate and bicarbonate found during mastitis may be responsible for an elevated $\mathrm{pH}$ in mastitis milk as reported by Ogola et al., (2007). The present findings regarding a decrease in Fat corroborates with the findings of Holdaway (1990) who stated that over a period of time, the total output of fat from a quarter is likely to be reduced, because of lower volume of milk. Also, the size of fat droplets is bigger relatively to that of intracellular gaps and so contained within the alveoli and consequently their concentration increases which corroborates with the findings of Auldist and Hubble, (1998). The study reported that the milk with high SCC is more susceptible to spontaneous lipolysis. Lipase enzymes produced by the leukocytes at the mammary gland after infection are mainly responsible for the lipolysis of milk fat globule membranes, resulting in the breakdown of triglycerides and oxidation of fatty acids. Batavani et al., (2007) concluded about elevated sodium, chloride, $\mathrm{pH}$, albumin, lactate dehydrogenase (LDH) activity and immunoglobins in mastitis milk. In contrast, decreased values were found for calcium, inorganic phosphorus, potassium, alpha-lactalbumin and beta-lactoglobulin. Ogola et al., (2007) reported significant increase in $\mathrm{Na}$, Chloride and free fatty acids in mastitis milk samples while stated a significant lower value for lactose, casein-tototal protein, potassium and calcium. The results in these studies were linked to the reduced secretory activities of the mammary cells and increased permeability of the mammary epithelium. This can lead to the transfer of blood components to the milk. Hamadani et al., (2013) reported a decrease in calcium concentrations in mastitis milk which is attributed to the disruption of casein. The ionic content of milk varies greatly in mastitis which plays a significant role in processing of milk samples and it's quality. Pottasium is found to be the most abundant mineral in milk, leaks out of milk through the paracellular pathway resulting a decrease in it's concentration. Alternatively, $\mathrm{Na}^{+}$found abundantly in blood, leaks into the milk resulting in an increasing concentration in mastitis milk. Due to heavy influx of blood constituents into the milk in infections i.e. in mastitis, the concentration of chloride is found to be elevated. The concentration of chloride in mastitis milk elevated probably due to the influx of blood constituent into the milk during infection conversely, sodium, found in the blood in high quantities, leaks into the milk increasing concentrations above normal (Auldist \& Hubble, 1998). Increased electrical conductivity in mastitis milk in our study may be attributed to increase in $\mathrm{Na}+$ concentrations which corroborates with Rajak et al., (2015). 
Table.1 Mean \pm SE of Hematological alterations in cows affected with mastitis and apparently healthy cows reared in natural field conditions

\begin{tabular}{|c|c|c|}
\hline Parameters & Control $(\mathbf{n = 1 0})$ & Mastitis $(\mathbf{n}=\mathbf{6 0})$ \\
\hline Hb $($ gm \% $)$ & $10.65 \pm 0.27^{\mathrm{a}}$ & $8.8 \pm 0.11^{\mathrm{b}}$ \\
\hline TLC & $6960 \pm 177.8^{\mathrm{b}}$ & $10670 \pm 153.6^{\mathrm{a}}$ \\
\hline TEC & $5.53 \pm 0.12^{\mathrm{a}}$ & $4.66 \pm 0.06^{\mathrm{b}}$ \\
\hline PCV & $32.6 \pm 0.84^{\mathrm{a}}$ & $27.3 \pm 0.36^{\mathrm{b}}$ \\
\hline MCV & $58.95 \pm 0.28^{\mathrm{a}}$ & $58.07 \pm 0.47^{\mathrm{b}}$ \\
\hline MCHC & $32.68 \pm 0.05^{\mathrm{a}}$ & $32.35 \pm 0.08^{\mathrm{b}}$ \\
\hline Neutrophil & $35.10 \pm 1.47^{\mathrm{b}}$ & $50.96 \pm 0.59^{\mathrm{a}}$ \\
\hline Lymphocyte & $61.70 \pm 1.52^{\mathrm{a}}$ & $44.31 \pm 0.66^{\mathrm{b}}$ \\
\hline Eosinophil & $1.70 \pm 0.21^{\mathrm{b}}$ & $3.20 \pm 0.24^{\mathrm{a}}$ \\
\hline Monocyte & $1.50 \pm 0.16$ & $1.51 \pm 0.06$ \\
\hline
\end{tabular}

NB: Mean bearing different superscript differs significantly at $5 \%(\mathrm{P}<0.05)$

Table.2 Mean \pm SE of serum biochemical alterations in cows with mastitis and apparently healthy cows reared in natural field conditions

\begin{tabular}{|l|l|l|}
\hline Parameters & Control $(\mathbf{n}=\mathbf{1 0})$ & Mastitis $(\mathbf{n = 2 0})$ \\
\hline ALT & $10.60 \pm 0.01^{\mathrm{a}}$ & $10.17 \pm 0.01^{\mathrm{b}}$ \\
\hline AST & $88.70 \pm 1.24^{\mathrm{b}}$ & $106.2 \pm 1.60^{\mathrm{a}}$ \\
\hline Glucose & $58.13 \pm 0.16^{\mathrm{a}}$ & $56.43 \pm 0.09^{\mathrm{b}}$ \\
\hline Total Protein & $8.03 \pm 0.07^{\mathrm{b}}$ & $9.54 \pm 0.03^{\mathrm{a}}$ \\
\hline Ca & $10.75 \pm 0.15^{\mathrm{a}}$ & $8.11 \pm 0.09^{\mathrm{b}}$ \\
\hline P & $6.0 \pm 0.13^{\mathrm{a}}$ & $5.01 \pm 0.07^{\mathrm{b}}$ \\
\hline Na & $139.9 \pm 0.82^{\mathrm{b}}$ & $152.6 \pm 1.05^{\mathrm{a}}$ \\
\hline K & $3.98 \pm 0.06^{\mathrm{b}}$ & $5.12 \pm 0.07^{\mathrm{a}}$ \\
\hline
\end{tabular}

NB: Mean bearing different superscript differs significantly at $5 \%(\mathrm{P}<0.05)$

Table.3 Mean \pm SE of compositional changes in mastitis milk and normal milk

\begin{tabular}{|c|c|c|}
\hline Parameters & Normal Milk $(\mathbf{n = 1 0})$ & Mastitis Milk $(\mathbf{n = 1 5})$ \\
\hline pH & $6.4 \pm 0.03^{\mathrm{b}}$ & $6.9 \pm 0.2^{\mathrm{a}}$ \\
\hline Specific gravity & $1.030 \pm 0.001^{\mathrm{a}}$ & $1.027 \pm 0.003^{\mathrm{b}}$ \\
\hline A cidity & $0.1316 \pm 0.003^{\mathrm{a}}$ & $0.0853 \pm 0.002^{\mathrm{b}}$ \\
\hline Fat & $4.56 \pm 0.08^{\mathrm{a}}$ & $3.31 \pm 0.32^{\mathrm{b}}$ \\
\hline SNF & $8.30 \pm 0.05^{\mathrm{a}}$ & $7.6 \pm 0.06^{\mathrm{b}}$ \\
\hline Total Protein & $3.6 \pm 0.008^{\mathrm{a}}$ & $3.5 \pm 0.004^{\mathrm{b}}$ \\
\hline Whey Protein & $0.77 \pm 0.04^{\mathrm{b}}$ & $1.27 \pm 0.03^{\mathrm{a}}$ \\
\hline Na & $463.3 \pm 21.22^{\mathrm{b}}$ & $868.9 \pm 9.9^{\mathrm{a}}$ \\
\hline Electrical Conductivity & $13.48 \pm 0.05^{\mathrm{b}}$ & $14.54 \pm 0.11^{\mathrm{a}}$ \\
\hline
\end{tabular}

NB: Mean bearing different superscript differs significantly at $5 \%(\mathrm{P}<0.05)$ 


\section{Antibiotic residues in milk}

Mastitis milk samples tested through QuickSTAR strip reader resulted about presence of tetracyclines in majority of milk sample as antibiotic residues. This might be due to low cost, easy availability and rampant use of this antibiotic in field conditions by majority of the vets and paravets.

\section{Cytology of mastitis milk}

The cytology of mastitis milks showing presence of inflammatory cells along with numerous fat vacoules. There was clumping of cells as well as presence of lipid droplets in the stained smear. Ranjan et al., (2008) reported similar findings in the cytology of mastitis milk. Presence of inflammatory cells along with fat vacuoles attributed to the active host's response to infection in the mammary gland.

\section{Histopathology}

Histopathology of the representative tissue sample collected from chronic mastitis with blocked teat revealed the presence of ductal hemorrhages with adjacent fibrotic proliferation, polypoid fibrotic growth projecting into the lumen of teat canal, fibrosis along with ductal area filled with inflammatory cells.

There was presence of glandular lumen filled with erythrocytes. Some areas showed more proliferation of fibrotic cells along with congestion and hemorrhages and atrophic alveoli. In some cases, it was seen about extension of epidermal layer of the teat into fibrotic inner layers. Similar observations opined by several researchers such as Alawaa et al., (2000); Green M and Bradley A (2004); Davidov et al., (2011) and Hussain et al., (2013). Fibrotic proliferation along with presence of RBCs and inflammatory cells in glandular alveoli owes to animal's immune response against persistent infectious organisms.

Conclusively, present study of hematobiochemical alterations in mastitis cows along with compositional changes in milk may be helpful to the clinician in assessing the severity of the affection as well as advising necessary therapy. Increased prevalence of subclinical mastitis without any obvious clinical signs with alterations in composition of milk pose a problem in dairy industry related to processing of milk products and its quality. Awareness among the farmers with routine screening of milk should be advocated to curb down the menace of this economic devastating disease in time to come.

\section{Acknowledgement}

Authors express their sincere thanks to Dean, College of Veterinary Science \& Animal Husbandry, Orissa University of Agriculture and Technology for providing facilities and financial support.

\section{References}

Alawaa J P, Ngelea MB and Ogwub D. 2000. Chronic caprine mastitis in Nigerian goat breeds: microbiology and histopathological findings, Small Ruminant Research 35: 203-207.

Auldist M J and Hubble I B. 1998. Effects of mastitis on raw milk and dairy products, The Australian Journal of Dairy Technology 53: 28-36.

Babaei H, Mansouri N L, Molaei M M, Kheradmand A and Sharifan M. 2007. Assessment of lactate dehydrogenase, alkaline phosphatase and aspartate aminotransferase activities in cow's milk as an indicator of subclinical mastitis. Veterinary Research Communications 31(4): 419-425. 
Badran A E, Sharaby M A and Hassan G A. 1986. Susceptibility of cows and buffaloes to mastitis infection.2. Milk quality and mastitis infection, Indian Veterinary Journal 63(12): 1017-1022.

Batavani R A, Asri S and Naebzadeh H. 2007. The effect of subclinical mastitis on milk composition in dairy cows, Iranian Journal of Veterinary Research, University of Shiraz Vol. 8, No.3.

Davidov I, Bobos S, Radinovic $M$ and Erdeljan M. 2011. Impact of different thickness keratin layer of ductus papillaris on the state of udder parenchyma, Veterinarska Stanica 42 (Supplement 1): 161-165

Green M and Bradley A. 2004. Clinical Forum, Staphylococcus aureus mastitis in cattle, Uk Vet 9(4).

Guha A and Gera S.2011. Etio-prevalence of subclinical mastitis in Holstein $X$ Hariana crossbred cattle, EAMR. 1(1): 75-78.

Haggag H F, Hamzawi L F, Mahran G A and Ali M M. 1991. Physico-chemical properties of colostrum and clinical and subclinical mastitic buffalo milk, Egyptian Journal of Dairy Science 19(1): 55-63.

Holdaway R J. 1990. A comparison of methods for the diagnosis of bovine subclinical mastitis within New Zealand dairy herds. Thesis (Ph.D)- Massey University.

Hussain R, Javed M T, Khan A and Muhammad G. 2013. Risk factors associated with sub-clinical mastitis in water buffaloes in Pakistan, Tropical Animal Health Production 45: 17231729.

Jain J, Karnani M, Khan A and Sharma S. 2013. Comparative investigation of various biochemical parameters of cattle suffering from mastitis in semi arid Rajasthan, Journal of Immunology and Immunopathology 15 (1): 137.
Kumar S. 2012. Clinico - pathological studies of clinical mastitis in cows with special reference to therapeutic management. M.V.Sc. Thesis submitted to WBUAFS, Kolkata.

Ogola H, Shitandi A and Nanua J. 2007. Effect of mastitis on raw milk compositional quality, Journal of Veterinary Science 8(3): 237-242.

Radostits O M, Gay C C, Blood D C and Hinchcliff K W. 2000. Veterinary Medicine, W.B. Saunders, London.

Radostits O M, Gay C C, Hinchcliff K W and Constable P D. 2007. Veterinary medicine: a text book of the diseases of cattle, horses, sheep, pigs and goats. $10^{\text {th }}$ edition. WB Saunders Co. Ltd. Philadelphia. Pp 673-762.

Ranjan R, Gupta M K, Singh K K and Jha D $\mathrm{K}$ 2008. Comparative efficacy of Papanicolaou stain and Leishman stain in the cytological study of bovine mastitis, Indian Journal of Veterinary Pathology 32(2): 277-279.

Razak R., Hussain I, Dar P A, Ahmad S B and Mir M R. 2015. Relationship between serum amyloid A3 in serum and milk of mastitic cows, Applied Biological Research 17(3): 315-319.

Sahoo N and Parida G S. 2002. Studies on prevalence, control and economics of bovine mastitis. Project Report submitted to the Orissa University of Agriculture and Technology, Bhubaneswar with the financial support from the Department of Science and Technology, Govt. of Odisha.

Sarvesha K, Satyanarayana M L, Narayanaswamy H D, Rao S, Yathiraj S, Isloor S, Mukartal S Y, Singh S V and Anuradha M E. 2017. Haematobiochemical profile and milk leukocyte count in subclinical and clinical mastitis affected crossbred cattle, Journal of Experimental Biology and Agricultural Sciences 5(1): 1-6. 
Schalm O and Noorlander D. 1957. Experiments and observations leading to the development of California mastitis test, Journal of American Veterinary Medical Association 130, 199-204.

Schalm O W, Carrloll E J, and Jain N C. 1971. Bovine mastitis.1971 Edn. Lea and Febiger, Philadelphia, pp. 76-77, 82, 104, 123, 144.

Singh M and Ludri R S. 2000. Somatic cell counts in Marrah buffaloes (Bubalus bubalis) during different stages of lactation, parity and season, Asian Australasian Journal of Animal Sciences 14(2): 189-192.

Zaki M S, Batrawy N E, Sussan O, Mostafa S O, Fawzi O M and Awad I. 2010. Some biochemical studies on Friesian suffering from subclinical mastitis. Nature and Science 8 (4): 143-146.

Zaki M S, Sharaf N E, Mostafa S O, Fazwi O $M$ and Batrawy N E. 2008. Effect of subclinical mastitis on some biochemical and clinicopathological parameters in buffalo, AmericanEurasian Journal of Agricultural and Environmental Sciences 3 (2): 200-204.

Zeedan G S, Abdalhamed A M, Abdeen E, Ottai M E and Abdel-Shafy S. 2014. Evaluation of antibacterial effect of some Sinai medicinal plant extracts on bacteria isolated from bovine mastitis, Veterinary World 7(11).

\section{How to cite this article:}

Rajendra Kumar Tripathy, Prasana Kumar Rath, Bidyut Prava Mishra, Susen Kumar Panda and Biswadeep Jena. 2018. Clinico-Pathological and Compositional Changes in Milk of Mastitis Cows. Int.J.Curr.Microbiol.App.Sci. 7(06): 1680-1687. doi: https://doi.org/10.20546/ijcmas.2018.706.199 